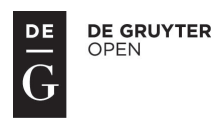

\title{
1EAC
}

\section{IN THE SHADOW OF THE STATE - THE INFORMAL ECONOMY AND INFORMAL ECONOMY LABOR FORCE}

\author{
Friedrich Schneider ${ }^{1}$
}

\begin{abstract}
In this paper, the main focus lies on the informal economy and on work in the shadow. The most influential factors on the informal economy are tax policies and state regulation. The size of the informal economy was decreasing over the period 1999 to 2007, from $34.0 \%$ to $31.2 \%$ for 161 countries (unweighted average). Furthermore, economic opportunities, taxes and regulations, the general situation on the labor market, and unemployment are crucial for an understanding of the dynamics of the shadow labor force. In contrast with the decrease of the informal economy (value added figures), the informal economy labor force increased for most countries over the period 1999 to 2007.
\end{abstract}

\section{Keywords}

Informal Economy, Undeclared Work, Shadow Labor Force, Tax Morale, Tax Pressure, State Regulation, Labor Market

\section{Introduction}

Fighting tax evasion, the informal economy and informal (illegal or shadow) employment have been important policy goals in OECD countries during recent decades. In order to meet these goals, one should have knowledge about the size and development of the informal economy and informal economy labor force, as well as the reasons why people are engaged in informal economy activities. This is the content of this paper. Tax evasion is not considered in order to keep the subject of this paper tractable and because too many additional aspects would be involved ${ }^{2}$. Also, tax morale or experimental studies on tax compliance are beyond the scope of this paper ${ }^{3}$.

\footnotetext{
${ }^{1}$ Johannes Kepler University of Linz, Department of Economics, Altenbergerstr. 69, A-4040 Linz, Austria. E-mail: friedrich.schneider@jku.at.

2 See Andreoni, Erard and Feinstein (1998) for the authoritative survey, Feld and Frey (2007) or Kirchler (2007) for broader interdisciplinary approaches, or the papers by Kirchler, Maciejovsky and Schneider (2003), Kastlunger, Kirchler, Mittore and Pitters (2009), Kirchler, Hoelzl and Wahl (2007).

3 The authoritative scientific work on tax morale is by Torgler (2007). See also Torgler (2002) for a survey on experimental studies and Blackwell (2010) for a meta-analysis.
} 
My paper is organized as follows: Section 2 presents theoretical considerations about the definition and measurement of the informal economy and also discusses the main factors determining its size. In Section 3, the empirical results of the size and development of the informal economy are discussed. In Section 4, a discussion of the size and development of the informal economy labor force is presented. Finally, Section 5 concludes.

\section{Some theoretical considerations about the informal economy}

\section{Defining the Informal Economy}

Up to today, authors trying to measure the informal economy face the difficulty of a precise definition of the informal economy. ${ }^{4}$ According to one commonly used definition, it comprises all currently unregistered economic activities that contribute to the officially calculated Gross National Product. ${ }^{5}$ Smith $(1994$, p. 18) defines it as "market-based production of goods and services, whether legal or illegal, that escapes detection in the official estimates of GDP". Put differently, one of the broadest definitions is: “. . those economic activities and the income derived from them that circumvent or otherwise avoid government regulation, taxation or observation". ${ }^{6}$

In this paper, the following more narrow definition of the informal economy is used. ${ }^{7}$ The informal economy includes all market-based legal production of goods and services that are deliberately concealed from public authorities for the following reasons:

1. to avoid payment of income, value added or other taxes,

2. to avoid payment of social security contributions,

3. to avoid having to meet certain legal labor market standards, such as minimum wages, maximum working hours, safety standards, etc., and

4. to avoid complying with certain administrative obligations, such as completing statistical questionnaires or other administrative forms.

\footnotetext{
${ }^{4}$ My paper focuses on the size and development of the informal economy for uniform countries and not for specific regions. Recently, the first studies have been undertaken to measure the size of the informal economy, as well as the "grey" or "shadow" labor force for urban regions or states (e.g. California). See, e.g. Marcelli, Pastor and Joassart (1999), Marcelli (2004), Chen (2004), Williams and Windebank (1998, 2001a, b), Flaming, Hayolamak, and Jossart (2005), Alderslade, Talmage and Freeman (2006), Brück, Haisten-DeNew and Zimmermann (2006). Herwartz, Schneider and Tafenau (2009) and Tafenau, Herwartz and Schneider (2010) estimate the size of the informal economy of 234 EU-NUTS regions for the year 2004, demonstrating considerable regional variation in the size of the informal economy.

${ }^{5}$ This definition is used, e.g. by Feige $(1989,1994)$, Schneider (1994a, 2003, 2005) and Frey and Pommerehne (1984). Do-it-yourself activities are not included. For estimates of the informal economy and the do-it-yourself activities for Germany, see Buehn, Karmann and Schneider (2009) or Karmann (1986, 1990).

${ }^{6}$ This definition is taken from Dell'Anno (2003), Dell'Anno and Schneider (2004) and Feige (1989); see also Thomas (1999), Fleming, Roman and Farrell (2000) or Feld and Larsen (2005, p. 25).

${ }^{7}$ See also the excellent discussion of the definition of the informal economy in Pedersen (2003, pp.13-19) and Kazemier (2005a), who uses a similar one.
} 


\section{Measuring the Informal Economy ${ }^{8}$}

The definition of the informal economy plays an important role in assessing its size. By having a clear definition, a number of ambiguities and controversies can be avoided. In general, there are two types of informal economic activities: illicit employment and in the household produced goods and services mostly consumed within the household. ${ }^{9}$ The following analysis focuses on both types, but tries to exclude illegal activities, such as drug production, crime and human trafficking. The in the household produced goods and services, e.g. schooling and childcare are not part of this analysis. Thus, it only focuses on productive economic activities that would normally be included in the national accounts but which remain underground due to tax or regulatory burdens. ${ }^{10}$ Although such legal activities contribute to the country's value added, they are not captured in the national accounts because they are produced in illicit ways (e.g. by people without proper qualifications or without a master craftsman's certificate). From the economic and social perspective, soft forms of illicit employment, such as moonlighting (e.g. construction work in private homes) and its contribution to aggregate value added can be assessed rather positively.

Although the issue of the informal economy has been investigated for a long time, the discussion regarding the "appropriate" methodology to assess its scope has not yet come to an end. ${ }^{11}$ There are three methods of assessment:

(1) Direct procedures at a micro level that aim to determine the size of the informal economy at one particular point in time. An example is the survey method;

(2) Indirect procedures that make use of macroeconomic indicators in order to proxy the development of the informal economy over time;

(3) Statistical models that use statistical tools to estimate the informal economy as an "unobserved" variable.

Today in many cases the estimation of the informal economy is based on a combination of the MIMIC procedure and on the currency demand method; or the use of only the currency demand method. ${ }^{12}$ The MIMIC procedure assumes that the informal economy remains an unobserved phenomenon (latent variable) which can be estimated using quantitatively

\footnotetext{
${ }^{8}$ Compare also Feld and Schneider (2010), Schneider (2011, 2014) and Schneider and Williams (2013).

${ }^{9}$ For a broader discussion of the definition issue, see Thomas (1992), Schneider, Volkert and Caspar (2002), Schneider and Enste (2002, 2006), Kazemier (2005a, b) and Buehn, Karmann and Schneider (2009).

${ }^{10}$ With this definition, the problem of having classical crime activities included could be avoided, because neither the MIMIC procedure nor the currency demand approach captures these activities: e.g. drug dealing is independent of increasing taxes, especially as the included causal variables are not linked (or causal) to classical crime activities. See, e.g. Thomas (1992), Kazemier (2005a, b) and Schneider (2005).

${ }^{11}$ For the strengths and weaknesses of the various methods, see Bhattacharyya (1999), Breusch (2005a, b), Dell'Anno and Schneider (2009), Dixon (1999), Feige (1989), Feld and Larsen (2005), Feld and Schneider (2010), Giles (1999a, b, c), Schneider (1986, 2001, 2003, 2005, 2006, 2011, 2014), Schneider and Enste (2000a, b, 2002, 2006), Tanzi (1999), Thomas (1992, 1999).

12 These methods are presented in detail in Schneider (1994a, b, c, 2005, 2011), Schneider and Williams (2013), Feld and Schneider (2010) and Schneider and Enste (2000b, 2002, 2006). Furthermore, these studies discuss advantages and disadvantages of the MIMIC and money demand methods as well as other estimation methods for assessing the size of illicit employment; for a detailed discussion, see also Feld and Larsen (2005).
} 
measurable causes of illicit employment, e.g. tax burden and regulation intensity, and indicators reflecting illicit activities, e.g. currency demand, official GDP and official working time. A disadvantage of the MIMIC procedure is the fact that it produces only relative estimates of the size and the development of the informal economy. Thus, the currency demand method ${ }^{13}$ is used to calibrate the relative into absolute estimates (e.g. as percentage of GDP) by using two or three absolute values (as percentage of GDP) of the size of the informal economy.

In addition, the size of the informal economy is estimated by using survey methods (Feld and Larsen $(2005,2008,2009)$ ). In order to minimize the number of respondents dishonestly replying or totally declining answers to the sensitive questions, structured interviews are undertaken (usually face-to-face) in which the respondents slowly become accustomed to the main purpose of the survey. As with the contingent valuation method (CVM) in environmental economics (Kopp et al. 1997), the first part of the questionnaire aims to shape respondents' perceptions to the issue at hand. In the second part, questions about respondents' activities in the informal economy are asked, and the third part contains the usual socio-demographic questions.

In addition to the studies by Merz and Wolff (1993), Feld and Larsen (2005, 2008, 2009), Haigner et al. (2013) and Enste and Schneider (2006) in Germany, the survey method has been applied in the Nordic countries and Great Britain (Isachsen and Strøm, 1985, Pedersen 2003) as well as in the Netherlands (van Eck and Kazemier, 1988, Kazemier, 2006). While the questionnaires underlying these studies are broadly comparable in design, recent attempts by the European Union to provide survey results for all EU member states runs into difficulties regarding comparability (Renooy et al., 2004, European Commission, 2007): the wording of the questionnaires becomes more and more cumbersome depending on the culture of different countries with respect to the underground economy.

To summarize: Although each method has its strength and weaknesses, and biases in the estimates of the informal economy almost certainly prevail, no better data are currently available. Clearly, there can be no exact measure of the size of the informal economy and estimates differ widely, with an error margin of $+/-15$ percent. These days, macro estimates derived from the MIMIC model, the currency demand method, or the electricity approach are seen as upper bound estimates, while micro (survey) estimates are seen as lower bound estimates.

\footnotetext{
${ }^{13}$ This indirect approach is based on the assumption that cash is used to make transactions within the informal economy. By using this method, one econometrically estimates a currency demand function, including independent variables such as the tax burden, regulation, etc. which "drive" the informal economy. This equation is used to make simulations of the amount of money that would be necessary to generate the official GDP. This amount is then compared with the actual money demand and the difference is treated as an indicator for the development of the informal economy. On this basis, the calculated difference is multiplied by the velocity of money of the official economy and one gets a value added figure for the informal economy. See footnote 11 for references critically discussing this method.
} 


\section{Theorizing about the Informal Economy}

A useful starting point for a theoretical discussion of the informal economy is the paper by Allingham and Sandmo (1972) on income tax evasion. While the informal economy and tax evasion are not congruent, activities in the informal economy in most cases imply the evasion of direct or indirect taxes, such that the factors determining tax evasion will most certainly also affect the informal economy. According to Allingham and Sandmo, tax compliance depends on its expected costs and benefits. The benefits of tax non-compliance result from the individual marginal tax rate and the true individual income. In the case of the informal economy, the individual marginal tax rate is often roughly calculated using the overall tax burden from indirect and direct taxes including social security contributions. The expected costs of non-compliance derive from deterrence enacted by the state, i.e., the state's auditing activities raising the probability of detection and the fines individuals face when they are caught.

Individuals are rational calculators who weigh the costs and benefits a legal status entails. Their decision to partially or completely participate in the informal economy is a choice under uncertainty facing a trade-off between the gains if their activities are not discovered and a loss if discovered and penalized. Informal economic activities SE thus negatively depend on the probability of detection $p$ and potential fines $f$, and positively on the opportunity costs of remaining formal denoted as B. The opportunity costs are positively determined by the burden of taxation $\mathrm{T}$ and high labor costs $\mathrm{W}-$ the individual income generated in the informal economy is usually categorized as labor income rather than capital income - due to labor market regulations. Hence, the higher the tax burden and labor costs, the more incentives individuals have to avoid those costs by working in the informal economy. The probability of detection $\mathrm{p}$ itself depends on enforcement actions A taken by the tax authority and on facilitating activities $\mathrm{F}$ accomplished by individuals to reduce detection of informal economic activities. This discussion suggests the following structural equation:

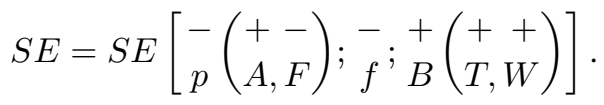

The informal economy thus focuses on productive economic activities that would normally be included in the national accounts but which remain underground due to tax or regulatory burdens. ${ }^{14}$ Although such legal activities would contribute to the country's value added, they are not captured in the national accounts because they are produced in illicit ways. Informal household economic activities such as do-it-yourself activities and neighborly help are typically excluded in the analysis of the informal economy. ${ }^{15}$

\footnotetext{
14 Although classical crime activities such as drug dealing are independent of increasing taxes and the causal variables included in the empirical models are only imperfectly linked (or causal) to classical crime activities, the footprints used to indicate informal economic activities such as currency in circulation also apply to classic crime. Hence, macroeconomic informal economy estimates typically do not distinguish legal from illegal underground activities; rather they represent the whole informal economy spectrum.

${ }^{15}$ From a social perspective, maybe even from an economic one, soft forms of illicit employment, such as
} 
Kanniainen, Pääkkönen and Schneider (2004) incorporate many of these insights in their model of the informal economy. They hypothesize that tax hikes unambiguously increase the informal economy, while the availability of public goods financed by taxes moderates participation in the informal economy. The latter effect depends, however, on the ability to access those public goods. A shortcoming of this analysis is the neglected endogeneity of tax morale and good governance, which is addressed by Feld and Frey (2007), who argue that tax compliance is the result of a complicated interaction between tax morale and deterrence measures. It must be clear to taxpayers what the rules of the game are and, as deterrence measures serve as signals for the level of tax morale a society wants to elicit (Posner, 2000), deterrence may also crowd out the intrinsic motivation to pay taxes. Tax morale does not only increase if taxpayers perceive the public goods received in exchange for their tax payments. It may also decrease if individuals perceive political decisions for public activities or the treatment of taxpayers by the tax authorities to be unfair. Tax morale is thus not exogenously given but influenced by deterrence and the quality of state institutions.

Table 1 presents an overview of the most important determinants influencing the informal economy. Due to space reasons, there is no detailed discussion of the various determinants/causes of the informal economy.

moonlighting (e.g. construction work in private homes) and its contribution to aggregate value added, may be assessed positively. For a discussion of these issues, see Thomas (1992) and Buehn, Karmann and Schneider (2009). 


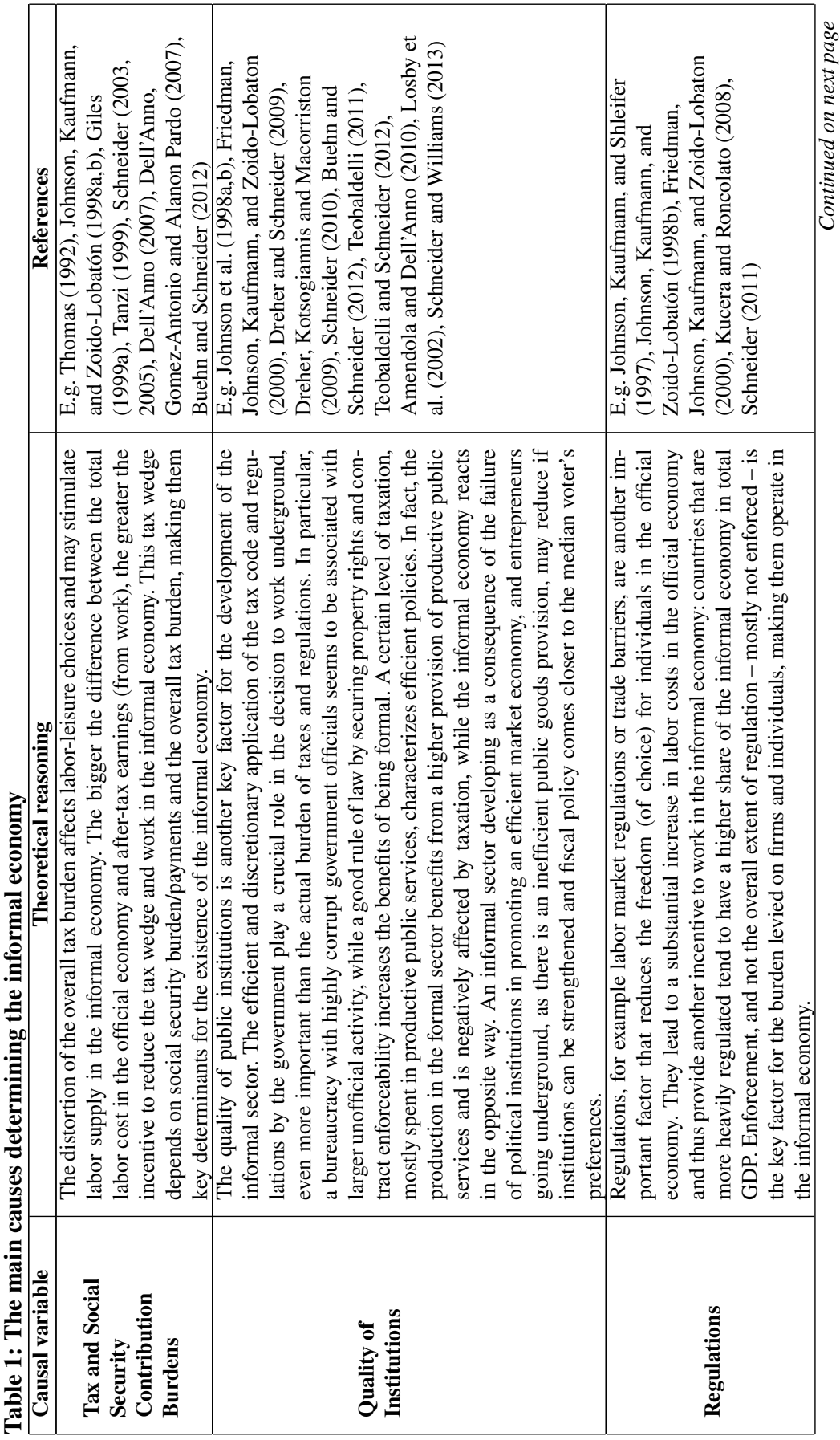




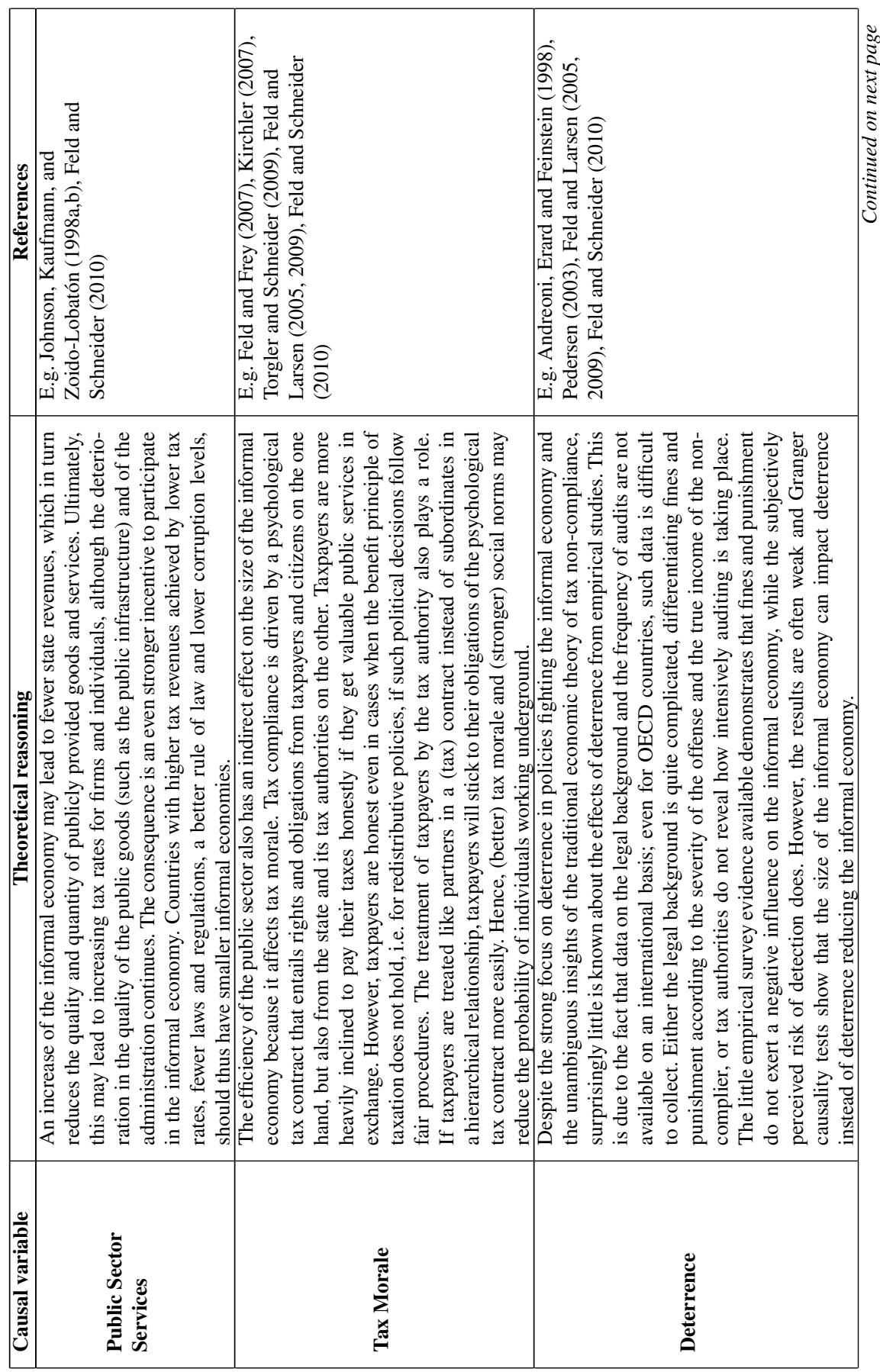


DOI: 10.2478/danb-2014-0013

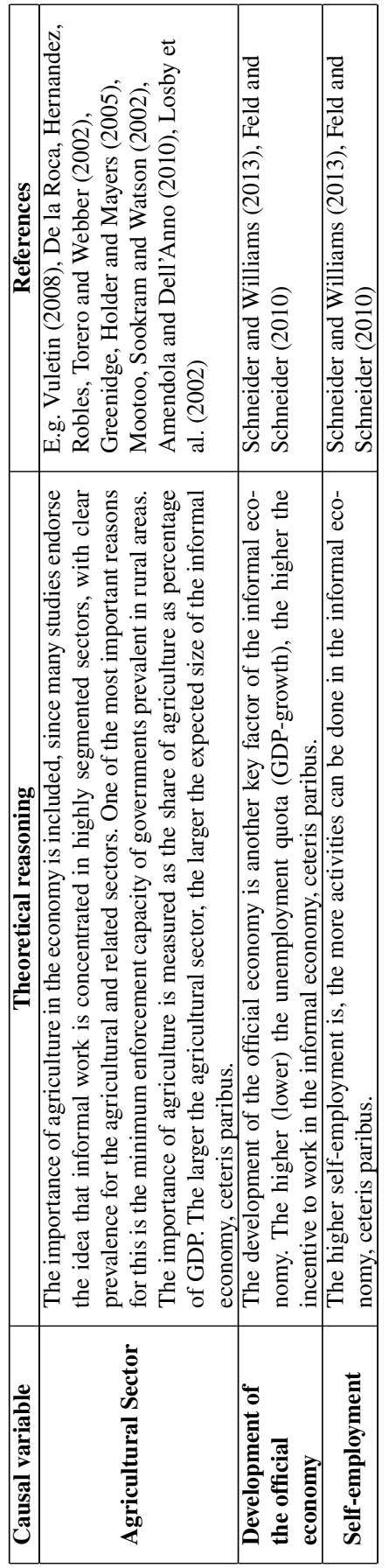




\section{Size of informal economies all over the world ${ }^{16}$}

Figure 1 shows the average size of the informal economy of 162 countries over the period 1999-2007. In tables 2 and 3, the average informality (unweighted and weighted) in different regions is shown using the regions defined by the World Bank. The World Bank distinguishes eight world regions: East Asia and Pacific, Europe and Central Asia, Latin America and the Caribbean, Middle East and North Africa, High Income OECD, Other High Income, South Asia, and Sub-Saharan Africa. If we first consider table 2, where the average informality (unweighted) is shown, we see that Latin America and the Caribbean have the highest value informal economies, at $41.1 \%$, followed by Sub-Saharan Africa, at $40.2 \%$, followed by Europe and Central Asia, with 38.9\%. The High Income OECD countries have the lowest, with $17.1 \%$. If we consider the average informality of the informal economies of these regions weighted by total GDP in 2005, Sub-Saharan Africa has the highest, with 37.6\%, followed by Europe and Central Asia, with $36.4 \%$ and Latin America and the Caribbean, with 34.7\%. Again, the High Income OECD has the lowest, at 13.4\%. If one considers the world mean weighted and unweighted, one sees that, if one uses the unweighted measures, the mean is $33.0 \%$ over the period 1999-2007. If we consider the world with weighted informality measures, the informal economy takes "only" a value of $17.1 \%$ over the period 1999-2007. Weighting the values makes a considerable difference. One general result of the size and development of the informal economies worldwide is that there is an overall reduction in the size. In figure 2, the size and development of the informal economy of various country groups (weighted averages by the official GDP of 2005) over 1999, 2003 and 2007 are shown. One clearly realizes that, for all country groups (25 OECD countries, 116 developing counties, and 25 transition countries), a decrease in the size of the informal economy can be observed. The average size of the informal economies of the 162 countries was $34.0 \%$ of official GDP (unweighted measure!) in 1999 and decreased to $31.2 \%$ of official GDP in 2007. This is a decrease of almost 3.0 percentage points over nine years. Growth of the official economy with reduced (increased) unemployment (employment) seems to be the most efficient means to reduce the informal economy.

\footnotetext{
${ }^{16}$ Some figures are taken from Schneider, Buehn and Montenegro (2010). The econometric MIMIC estimation results are not shown here due to space reasons; see, e.g. Schneider, Buehn and Montenegro (2010).
} 
DOI: 10.2478/danb-2014-0013

Table 2: Average Informality (Unweighted) by World Bank's Regions

\begin{tabular}{|l|l|c|c|c|c|c|}
\hline & Region & mean & median & min & max & sd \\
\hline EAP & East Asia and Pacific & 32.3 & 32.4 & 12.7 & 50.6 & 13.3 \\
\hline ECA & Europe and Central Asia & 38.9 & 39.0 & 18.1 & 65.8 & 10.9 \\
\hline LAC & Latin America and the Caribbean & 41.1 & 38.8 & 19.3 & 66.1 & 12.3 \\
\hline MENA & Middle East and North Africa & 28.0 & 32.5 & 18.3 & 37.2 & 7.8 \\
\hline OECD & High Income OECD & 17.1 & 15.8 & 8.5 & 28.0 & 6.1 \\
\hline OHIE & Other High Income & 23.0 & 25.0 & 12.4 & 33.4 & 7.0 \\
\hline SAS & South Asia & 33.2 & 35.3 & 22.2 & 43.9 & 7.0 \\
\hline SSA & Sub-Saharan Africa & 40.2 & 40.6 & 18.4 & 61.8 & 8.3 \\
\hline World & & 33.0 & 33.5 & 8.5 & 66.1 & 12.8 \\
\hline
\end{tabular}

Source: Schneider, Buehn and Montenegro (2010)

Table 3: Average Informality (Weighted) by Total GDP in 2005

\begin{tabular}{|l|l|c|c|c|c|c|}
\hline & Region & mean & median & min & max & sd \\
\hline EAP & East Asia and Pacific & 17.5 & 12.7 & 12.7 & 50.6 & 10.6 \\
\hline ECA & Europe and Central Asia & 36.4 & 32.6 & 18.1 & 65.8 & 8.4 \\
\hline LAC & Latin America and the Caribbean & 34.7 & 33.8 & 19.3 & 66.1 & 7.9 \\
\hline MENA & Middle East and North Africa & 27.3 & 32.5 & 18.3 & 37.2 & 7.7 \\
\hline OECD & High Income OECD & 13.4 & 11.0 & 8.5 & 28.0 & 5.7 \\
\hline OHIE & Other High Income & 20.8 & 19.4 & 12.4 & 33.4 & 4.9 \\
\hline SAS & South Asia & 25.1 & 22.2 & 22.2 & 43.9 & 5.9 \\
\hline SSA & Sub-Saharan Africa & 37.6 & 33.2 & 18.4 & 61.8 & 11.7 \\
\hline World & & 17.1 & 13.2 & 8.5 & 66.1 & 9.9 \\
\hline
\end{tabular}

Source: Schneider, Buehn and Montenegro (2010) 


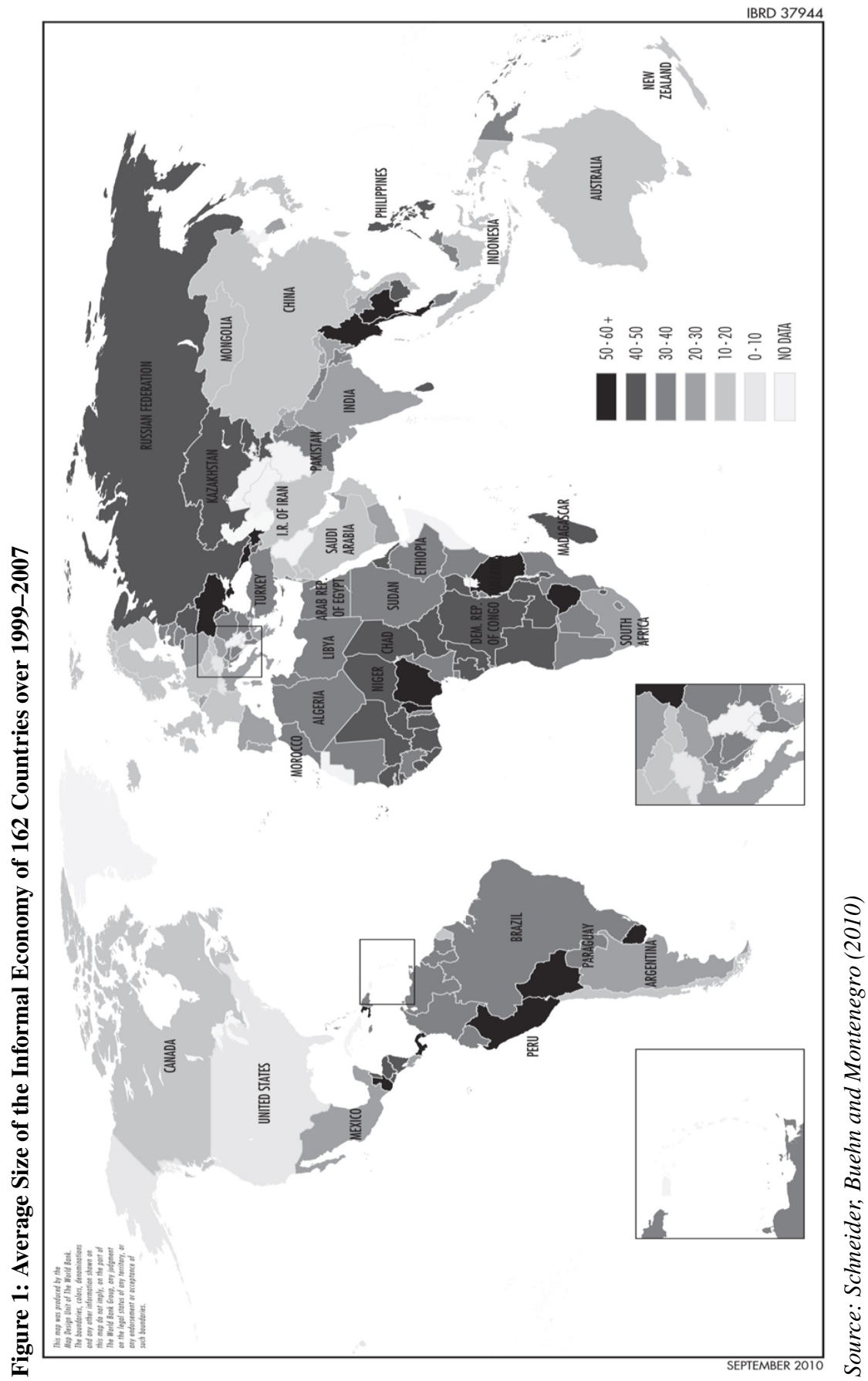


Figure 2: Size and Development of the Informal Economy of Various Country Groups (Weighted Averages (!); as percentage of official total GDP of the respective Country Group)

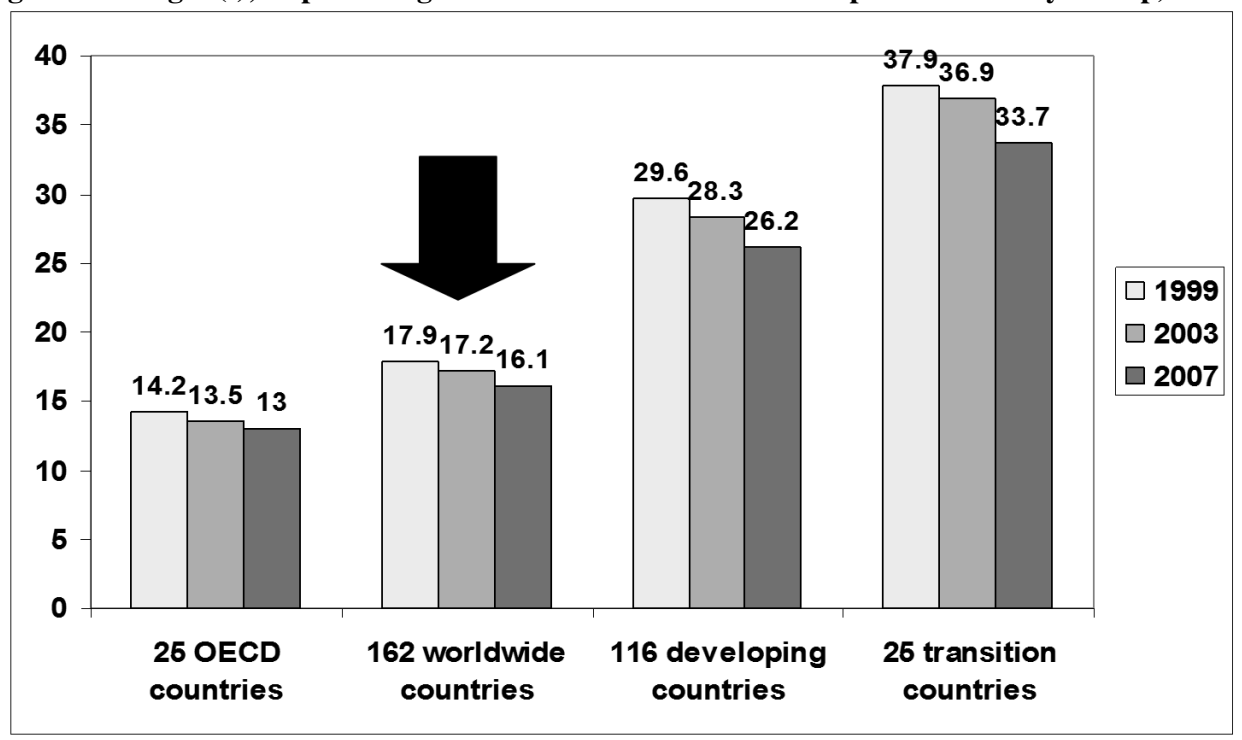

Source: Schneider, Buehn and Montenegro (2010)

\section{Informal Economy Labor Force}

The following results of the informal economy labor force are based on the OECD and World Bank database on informal employment in major cities and in rural areas, as well as on other sources mentioned in the footnotes of this chapter and the tables. The values of the informal economy labor force are calculated in absolute terms, and as a percentage of the official labor force, under the assumption that the informal economy in rural areas is at least as high as in the cities. This is a conservative assumption, since in reality it is likely to be even larger. ${ }^{17}$ Survey techniques and, for some countries, the MIMIC method and the method of the discrepancy between the official and actual labor force are used for estimation.

One of the most famous studies is the OECD (2009a, b) one titled "Is informal normal?", which provides worldwide figures. This OECD study ${ }^{18}$ concludes that, in many parts of the world and over the period 1990 to 2007, informal employment was the norm, not the exception. More than half of all jobs in the non-agricultural sectors of developing countries - over 900 million workers - can be considered informal. If agricultural workers

\footnotetext{
17 The assumption that the informal economy labour force is at least as high in rural areas as in major cities, is a very modest one and is supported by Lubell (1991). Some authors (e.g., Lubell (1991), Pozo (1996), and Chickering and Salahdine (1991)) argue that the illicit labour force is nearly twice as high in the countryside as in urban areas. But since no (precise) data exists on this ratio, the assumption of an equal size may be justified by arguing that such a calculation provides at least minimal figures.

18 The following results and figures are taken from the $\operatorname{OECD}(2009 \mathrm{a}, \mathrm{b})$, executive summary.
} 
in developing countries are included, the estimates come out at roughly 2,000 million people. The share of informal employment is also shown in figure 3 for Latin America and South East Asia. In some regions, including Sub-Saharan Africa and South Asia, over $80 \%$ of non-agricultural jobs are informal. Most informal workers in the developing world are self-employed and work independently, or own and manage very small enterprises. According to the OECD study (2009a, b), informal employment is a result of both people being excluded from official jobs and people voluntarily opting out of formal structures, e.g. in many middle income countries, incentives drive individuals and businesses out of the formal sector.

To summarize, this OECD study clearly comes to the conclusion that informal is really the norm or the normal case. 1.8 billion people work in informal jobs, compared to 1.2 billion who benefit from formal contracts and social security protection. Informal economic activity, excluding the agricultural sector, accounts for three-quarters of the jobs in Sub-Saharan Africa, for more than two-thirds in South and South East Asia, half in Latin America, the Middle East and North Africa, and nearly one-quarter in transition countries. If agriculture is included, the informal share of the economy in the abovementioned regions is even higher (e.g. more than $90 \%$ in South Asia). Also, this OECD study arrives at the result that more than 700 million informal workers "survive" on less than $\$ 1.25$ a day and some 1.2 billion on less than $\$ 2$ a day. The study also concludes that the share of informal employment tends to increase during economic turmoil. For example, during the Argentine economic crisis (1999-2002), the country's "official" economy shrank as by almost one-fifth while the share of informal employment expanded from 48 to 52 percent. One can clearly see that, even under conditions of strong economic growth, the share of non-agricultural employment and the share of informal employment is strongly rising.

Figure 3: Informal Employment and GDP in Latin America and Southeast Asia

Part 1: Latin America

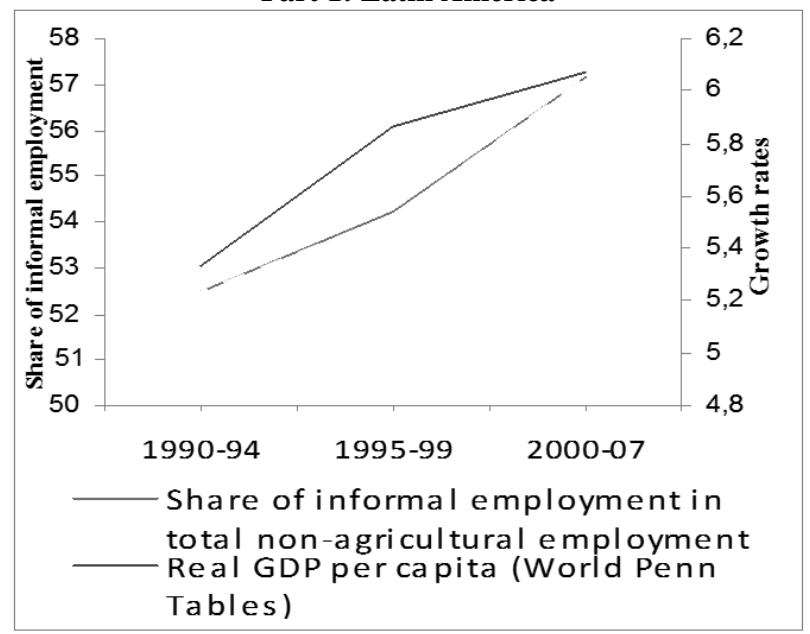


Part 2: Southeast Asia

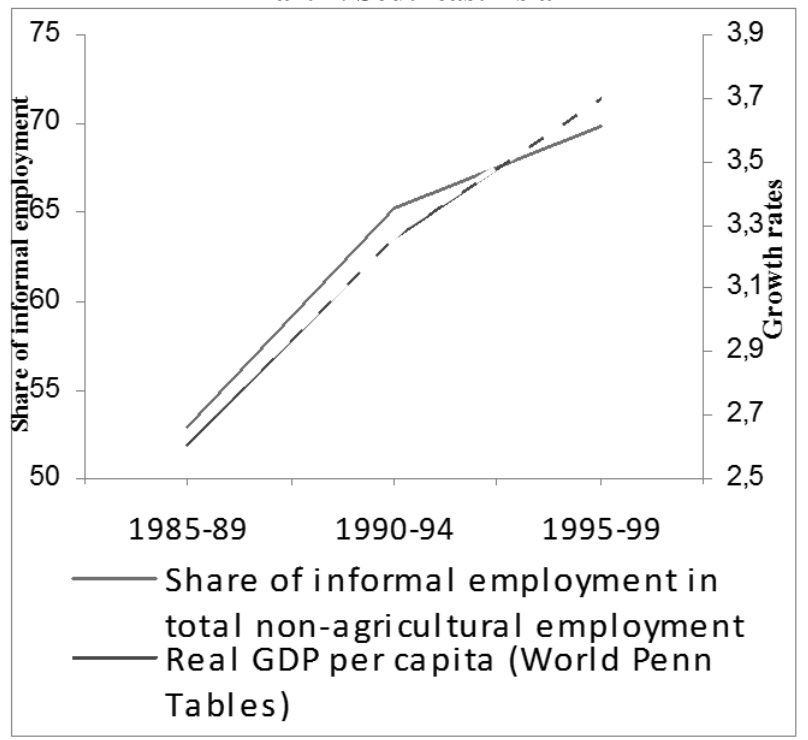

Source: OECD, Is Informal Normal, Paris, 2009a, $b$.

In table 4, the share of informal employment in total non-agricultural employment over a five-year period and by region is presented. From the table, one clearly sees that in all regions the share of informal employment has remarkably increased over time. The share of informal employment in South- and Middle-American countries in the period 1985-1989 was $32.4 \%$ and increased in the period 2000-2007 to 50.1\%. In 34 Asian countries, informal employment rose in the period 1985-1989 from $55.9 \%$ to $70.2 \%$ from 2000 to 2007. In the 42 African countries, the share of informal employment (as a percentage of total non-agricultural employment) was $40.3 \%$ from $1985-1989$, and increased to $60.5 \%$ in 2000-2007. Table 4 clearly demonstrates that there is a very strong positive trend in the share of informal employment (as a percentage of total non-agricultural employment).

Table 4: Share of Informal Employment in Total Non-Agricultural Employment by five-year period in $\%$

\begin{tabular}{|l|c|c|c|c|}
\hline \multirow{2}{*}{ Region } & \multicolumn{4}{|c|}{$\begin{array}{c}\text { Average Share of Informal Employment in \% } \\
\text { of Local Non Agricultural Employment over }\end{array}$} \\
\cline { 2 - 5 } & $\mathbf{1 9 8 5 - 8 9}$ & $\mathbf{1 9 9 0 - 9 4}$ & $\mathbf{1 9 9 5 - 9 9}$ & $\mathbf{2 0 0 0 - 0 7}$ \\
\hline $\begin{array}{l}\text { 22 South- and Middle American } \\
\text { Countries }\end{array}$ & 32.4 & 35.4 & 40.3 & 50.1 \\
\hline 34 Asian Countries & & & & \\
\hline 42 African Countries & 55.9 & 60.4 & 65.4 & 70.2 \\
\hline 21 Transition Countries & 40.3 & 47.1 & 52.4 & 60.5 \\
\hline
\end{tabular}

Source: OECD 2009a, b, pages 34-35; and Charmes (2002, 2007, 2008) for the ILO Women and Men in the Informal Economy, 2002. Note: For the most recent period: Heintz and Chang (2007) for the ILO, and for West Asia: Charmes (2007 and 2008). 


\section{Conclusion}

In this paper, some of the most recent developments in research on the informal economy and undeclared work in highly developed OECD, developing and transition countries are shown. The discussion of the recent literature shows that economic opportunities for employees, the overall situation on the labor market, not least unemployment, are crucial for an understanding of the dynamics of the informal economy. Individuals look for ways to improve their economic situation and thus contribute productively to the aggregate income of a country. This holds regardless of whether they are active in the official or the unofficial economy.

A further question is: What type of policy conclusions can I draw? One conclusion may be that - besides the indirect tax and personal income tax burden, which the government can directly influence by policy actions - self-employment and unemployment are two very important driving forces of the informal economy. Unemployment may be controllable by the government through economic policy in a traditional Keynesian sense; alternatively, the government can try to improve the country's competitiveness to increase foreign demand. The impact of self-employment on the informal economy is less or only partly controllable by the government and may be ambiguous from a welfare perspective. A government can deregulate the economy or incentivize "be your own entrepreneur", which would make self-employment easier, potentially reducing unemployment and positively contributing to efforts aimed at controlling the size of the informal economy. Such actions, however, need to be accompanied by a strengthening of institutions and tax morale to reduce the probability that the self-employed shift reasonable proportions of their economic activities into the informal economy, which, if it happened, would make government policies incentivizing self-employment less effective. This paper clearly shows that a reduction in the informal economy can be achieved using various channels the government can influence. The main challenge is still to bring informal economic activities into the official economy in such a way that goods and services previously produced in the informal economy are still produced and provided, but rather in the official economy. Only then can the government get additional taxes and social security contributions.

Finally, if I ask myself what we know about the informal economy and work in the shadow, I clearly realize that we have some knowledge about the size and development of the informal economy and the size and development of the informal economy labor force. For developing countries, the informal economy labor force has reached a remarkable size, according to $\operatorname{OECD}(2009 \mathrm{a}, \mathrm{b})$ estimates, which is that, in most developing countries, the informal economy labor force is greater than the official labor force. What we do not know are the exact motives, why people work in the informal economy and what is their relation and feeling if a government undertakes reforms in order to bring them back into the official economy. Hence, many more micro studies are needed to obtain more detailed knowledge about people's motivation to work in either the informal economy and/or in the official one. 


\section{References}

Alderslade, J., Talmage, J. and Freeman, Y. (2006). Measuring the Informal Economy: One Neighborhood at a Time, Discussion Paper, The Brooking Institution Metropolitan Policy Program, Washington D.C., September 2006.

Allingham, M. G., Sandmo, A. (1972). Income tax evasion: a theoretical analysis. Journal of Public Economics, 1(3-4), 323-338.

Amendola, A. and Dell'Anno, R. (2010). Institutions and Human Development in the Latin American Shadow Economy, Estudios en Derecho y Gobierno, 3/1, 9-25.

Andreoni, J., Erard, B. and Feinstein, J. (1998). Tax Compliance, Journal of Economic Literature, 36/4, 818-860.

Bhattacharyya, D. K. (1999). On the Economic Rationale of Estimating the Hidden Economy, Economic Journal, 109/3, 348-359.

Blackwell, C. (2010). A Meta Analysis of Incentive Effects in Tax Compliance Experiments. In Alm, J.; Martinez-Vazquez, J. and Torgler, B. (eds.). Developing Alternative Frameworks Explaining Tax Compliance. London: Routledge Publishing Company, 97-112.

Breusch, T. (2005a). The Canadian Underground Economy: An Examination of Giles and Tedds, Canadian Tax Journal, 53/4, 367-391.

Breusch, T. (2005b). Estimating the Underground Economy Using MIMIC Models, Working Paper, Canberra, Australia, http://econwpa.wustl.edu/eps/em/papers/0507/0507003.pdf.

Brück, T., Haisten-DeNew, J. B. and Zimmermann, K. F. (2006). Creating Low-Skilled Jobs by Subsidizing Market Contracted Household Work, Applied Economics, 38/4, 899-911.

Buehn, A. and Schneider, F. (2012). Shadow Economies Around the World: Novel Insights, Accepted Knowledge, and New Estimates, International Tax and Public Finance, 19, 139-171.

Buehn, A., Karmann, A. and Schneider, F. (2009). Shadow Economy and Do-it-yourself Activities: The German Case, Journal of Institutional and Theoretical Economics, 165/4, 701-722.

Charmes, J. (2002). Informal Sector, Poverty and Gender: A Review of the Empirical Evidence, Paper prepared on behalf of Wiego (Women in Informal Employment: Globalizing and Organizing), OECD and World Bank, Washington and Paris, 2002.

Charmes, J. (2007). Informal Sector Poverty and Gender, A Review of Empirical Evidence, Paper prepared on behalf of Wiego (Women in Formal Employment Globalizing and Organizing), OECD and World Bank, Washington and Paris, 2007.

Charmes, J. (2008). Informal Sector Poverty and Gender, A Review of Empirical Evidence, Paper prepared on behalf of Wiego (Women in Formal Employment Globalizing and Organizing), OECD and World Bank, Washington and Paris 2008.

Chen, M. (2004). Rethinking the Informal Economy: Linkages with the Formal Economy and the Formal Regulatory Environment, Paper presented at the EGDI-WIDR Conference Unleashing Human Potential: Linking the Informal and Formal Sectors, Helsinki, Finland, 2004. 
Chickering, L. A. and Salahdine, M. (eds.). (1991). The Silent Revolution - The Informal Sector in Five Asian and near Eastern Countries, An International Center for Economic Growth Publication (ICS Press), San Francisco.

De la Roca, J., Hernandez, M., Robles, M., Torero, M. and Webber, M. (2002). Informal Sector Study for Jamaica, Group of Analysis for Development, Inter-American Development Bank, Washington D.C.

Dell'Anno, R. (2003). Estimating the Shadow Economy in Italy: a Structural Equation Approach, Working Paper 2003-7, Department of Economics, University of Aarhus.

Dell'Anno, R. (2007). The Shadow Economy in Portugal: An Analysis with the MIMIC Approach, Journal of Applied Economics, 10, 253-277.

Dell'Anno, R. and Schneider, F. (2004). The Shadow Economy of Italy and other OECD Countries: What Do We Know?, Journal of Public Finance and Public Choice, 21, 223-245.

Dell'Anno, R. and Schneider, F. (2009). A Complex Approach to Estimate Shadow Economy: The Structural Equation Modelling. In Faggnini, M. and Looks, T. (eds.). Coping with the Complexity of Economics. Berlin: Springer, 110-130.

Dell'Anno, R., Gomez-Antonio, M. and Alanon Pardo, A. (2007). Shadow Economy in three different Mediterranean Countries: France, Spain and Greece. A MIMIC Approach, Empirical Economics, 33, 51-84.

Dixon, H. (1999). Controversy, On the Hidden Economy, Editorial introduction, Economic Journal, 456/3, 335-337.

Dreher, A. and Schneider, F. (2009). Corruption and the Shadow Economy: An Empirical Analysis, Public Choice, 144/2, 215-277.

Dreher, A., Kotsogiannis, C. and McCorriston, S. (2009). How Do Institutions Affect Corruption and the Shadow Economy?, International Tax and Public Finance, 16/4, 773-796. Eck, R. van and Kazemier, B. (1988). Features of the Hidden Economy in the Netherlands, Review of Income and Wealth, 34/3, 251-273.

Enste, D. and Schneider, F. (2006). Umfang und Entwicklung der Schattenwirtschaft in 145 Ländern. In Schneider, F. and Enste, D. (eds.). Jahrbuch Schattenwirtschaft 2006/07. Zum Spannungsfeld von Poltik und Ökonomie. LIT Verlag, Berlin, 55-80.

European Commission. (2007). Stepping up the fight against undeclared work, COM (2007) 628 final, Brussels: European Commission.

Feige, E. L. (ed.). (1989). The Underground Economies. Tax Evasion and Information Distortion, Cambridge University Press, Cambridge.

Feige, E. L. (1994). The Underground Economy and the Currency Enigma, Supplement to Public Finance/ Finances Publiques, 49, 119-136.

Feld, L. P. and Frey, B. S. (2007). Tax Compliance as the Result of a Psychological Tax Contract: The Role of Incentives and Responsive Regulation, Law and Policy, 29/1, 102-120. Feld, L. P. and Larsen, C. (2005). Black Activities in Germany in 2001 and 2004: A Comparison Based on Survey Data, Study No. 12, The Rockwool Foundation Research Unit, Copenhagen.

Feld, L. P. and Larsen, C. (2008). "Black" Activities Low in Germany in 2006, News from the Rockwool Foundation Research Unit, March 2008, 1-12. 
Feld, L. P. and Larsen, C. (2009). Undeclared Work in Germany 2001-2007 - Impact of Deterrence, Tax Policy, and Social Norms: An Analysis Based on Survey Data, Springer, Berlin et al.

Feld, L.P. and Schneider, F. (2010), Survey on the Shadow Economy and Undeclared Earnings in OECD Countries, German Economic Review, 11/2, 109-149.

Flaming, D., Hayolamak, B. and Jossart, P. (2005). Hopeful Workers, Marginal Jobs: LA's Off-The-Books Labor Force, Economic Roundtable, Los Angeles, CA, 2005.

Fleming, M.H., Roman, J. and Farrel, G. (2000). The Shadow Economy, Journal of International Affairs, Spring 2000, 53/2, 64-89.

Frey, B. S. and Pommerehne, W. (1984). The Hidden Economy: State and Prospect for Measurement, Review of Income and Wealth, 30/1, 1-23.

Friedman, E., Johnson, S., Kaufmann, D. and Zoido-Lobatón, P. (2000). Dodging the Grabbing Hand: The Determinants of Unofficial Activity in 69 Countries, Journal of Public Economics, 76/4, 459-493.

Giles, D.E. A. (1999a). Measuring the Hidden Economy: Implications for Econometric Modelling, Economic Journal, 109/3, 370-380.

Giles, D. E. A. (1999b). Modelling the Hidden Economy in the Tax-Gap in New Zealand, Empirical Economics, 24/ 4, 621-640.

Giles, D.E. A. (1999c). The Rise and Fall of the New Zealand Underground Economy: Are the Reasons Symmetric?, Applied Economic Letters, 6, 185-189.

Greenidge, K., Holder, C. and Mayers, S. (2005). Estimating the Size of the Underground Economy in Barbados, paper presented at the 26th Annual Review Seminar, Research Department, Central Bank of Barbados, July 26-29, 2005.

Haigner, S., Jenewein, S., Schneider, F. and Wakolbinger, F. (2013). Driving Forces of Informal Labour Supply and Demand Supply in Germany, International Labour Review, 152/3-4, 507-524.

Heintz, E. and Chang, G. B. (2007). Report of Informal Employment for the ILO, ILO Geneva.

Herwartz, H., Schneider, F. and Tafenau, E. (2009). One Share Fits It All? Regional Variation in the Shadow Economy in the EU Regions, Discussion paper, Universities of Linz and Kiel.

Isachsen, A. J. and Strøm, S. (1985). The Size and Growth of the Hidden Economy in Norway, Review of Income and Wealth, 31/1, 21-38.

Johnson, S., Kaufmann, D. and Shleifer, A. (1997). The Unofficial Economy in Transition, Brookings Papers on Economic Activity, 2, 159-221.

Johnson, S., Kaufmann, D. and Zoido-Lobatón, P. (1998a). Regulatory Discretion and the Unofficial Economy, American Economic Review, Papers and Proceedings, 88(2), 387-392. Johnson, S., Kaufmann, D. and Zoido-Lobatón, P. (1998b). Corruption, Public Finances and the Unofficial Economy, World Bank Policy Research Working Paper Series No. 2169, The World Bank, Washington, D.C.

Kanniainen, V., Pääkkönen, J., Schneider, F. (2004). Fiscal and Ethical Determinants of Shadow Economy: Theorey and Evidence. Discussion Paper. Linz: Johannes Kepler University of Linz. 
Karmann, A. (1986). Monetäre Ansätze zur Erfassung der Schattenwirtschaft: Ein Vergleich verschiedener Messansätze, Kredit und Kapitel, 19, 233-247.

Karmann, A. (1990). Schattenwirtschaft und ihre Ursachen: Eine empirische Analyse zur Schwarzwirtschaft und Selbstversorgung in der Bundesrepublik Deutschland, Zeitschrift für Wirtschafts- und Sozialwissenschaften (ZWS), 110, 185-206.

Kastlunger, B., Kirchler, E., Mittore, L. and Pitters, J. (2009), Sequences of Audits, Tax Compliance, and Taxpaying Strategies, Journal of Economic Psychology, 30/4, 405-418. Kazemier, B. (2005a). The Undergroud Economy: A Survey of Methods and Estimates, Discussion Paper, Statistics Netherlands, Voorburg, Netherlands.

Kazemier, B. (2005b). Monitoring the Underground Labor Market: What Surveys Can Do, Discussion Paper, Statistics Netherlands, Voorburg, Netherlands.

Kazemier, B. (2006). Monitoring the Underground Economy: A Survey of Methods and Estimates. In Schneider, F. and Enste, D. (eds.). Jahrbuch Schattenwirtschaft 2006/07. Zum Spannungsfeld von Politik und Ökonomie. LIT Verlag, Berlin, 11-53.

Kirchler, E. (2007). The Economic Psychology of Tax Behaviour, Cambridge (UK) University Press, Cambridge.

Kirchler, E., Hoelzl, E. and Wahl, I. (2007). Enforces versus Voluntary Tax Compliance: The "Slippery Slope" Framework, Journal of Economic Psychology, 29/2, 210-225.

Kirchler, E., Maciejovsky, B. and Schneider, F. (2003). Everyday Representations of Tax Avoidance, Tax Evasion and Tax Flight: Do Legal Differences Matter?, Journal of Economic Psychology, 24/4, 535-553.

Kopp, R. J., Pommerehne, W. W. and Schwarz, N. (1997). Determining the Value of NonMarketed Goods: Economic, Psychological, and Policy Relevant Aspects of Contingent Valuation Methods, Boston, (USA), Kluwer Academic Publishing Company.

Kucera, D. and Roncolato, L. (2008). Informal Employment: Two Contested Policy Issues, International Labor Review, 147/3, 321-348.

Losby, J. L., Else, J. F., Kingslow, M. E., Edgcomb, E. L., Malm, E. T. and Kao, V. (2002). Informal Economy Literature Review, The Aspen Institute, Microenterprise Fund for Innovation, Effectiveness, Learning and Dissemination, Washingtion D.C., and ISED Consulting and Research, Newark DE.

Lubell, H. (1991). The Informal Sector in the 1980s and 1990s, OECD, Paris.

Marcelli, E. A. (2004). Unauthorized Mexican Immigration, the Labour and other LowerWage Informal Employment in California, Regional Studies, 38/1, 1-13.

Marcelli, E. A., Pastor, M. jr. and Joassart, P. M. (1999). Estimating the Effects of Informal Economic Activity: Evidence from Los Angeles County, Journal of Economic Issues, 33, 579-607.

Merz, J. and Wolff, K. G. (1993). The Shadow Economy: Illicit Work and Household Production - A Microanalysis of West Germany, Review of Income and Wealth, 39/2, 177-194. Mootoo, L., Sookram, S. and Watson, P. K. (2002). Size and Structure of the Hidden Economy in the Caribbean, Economic Measurement Unit, Department of Economics, University of the West Indies, St. Augustine, Trinidad \& Tobago.

OECD. (2009a). Is Informal Normal? Towards More and Better Jobs, OECD, Paris. 
OECD. (2009b). Policy Round Tables, Competition Policy and the Informal Economy, OECD, Paris.

Pedersen, S. (2003). The Shadow Economy in Germany, Great Britain and Scandinavia: A Measurement Based on Questionnaire Service, Study No. 10, The Rockwool Foundation Research Unit, Copenhagen.

Posner, E. A. (2000). Law and Social Norms. Cambridge: Harvard University Press.

Pozo, S. (ed.). (1996). Exploring the Underground Economy: Studies of Illegal and Unreported Activity, W.E. Upjohn, Institute for Employment Research, Michigan.

Renooy, P., Ivarsson, S., van der Wusten-Gritsai, O. and Meijer, E. (2004). Undeclared Work in an Enlarged Union - An Analysis of Undeclared Work: An In-Depth Study of Specific Items, European Commission, Brussels.

Schneider, F. (1986). Estimating the Size of the Danish Shadow Economy Using the Currency Demand Approach: An Attempt, Scandinavian Journal of Economics, 88/4, 643-668.

Schneider, F. (1994a). Measuring the Size and Development of the Shadow Economy. Can the Causes be Found and the Obstacles be Overcome? In Brandstaetter, H. and Güth, W. (eds.). Essays on Economic Psychology. Springer, Berlin et al., 193-212.

Schneider, F. (1994b). Determinanten der Steuerhinterziehung der Schwarzarbeit im internationalen Vergleich. In Smekal, C. and Theurl, E. (eds.). Stand und Entwicklung der Finanzpsychologie. Nomos, Baden-Baden, 247-288.

Schneider, F. (1994c). Can the Shadow Economy be Reduced Through Major Tax Reforms? An Empirical Investigation for Austria, Supplement to Public Finance/ Finances Publiques, $49,137-152$.

Schneider, F. (2001). Die Schattenwirtschaft - Tatbestand, Ursachen, Auswirkungen, in: A. Rauscher (ed.), Die Arbeitswelt im Wandel, J. P. Bachem, Köln, 127-143.

Schneider, F. (2003). Shadow Economy. In Rowley, C. K. and Schneider, F. (eds.). Encyclopedia of Public Choice. Vol. II, Kluwer Academic Publishers, Dordrecht, 286-296. Schneider, F. (2005). Shadow Economies around the World: What Do We Really Know? European Journal of Political Economy, 21/4, 598-642.

Schneider, F. (2006). Shadow Economies and Corruption All Over the World: What Do We Really Know?, Universität Linz: Institut für Volkswirtschaftslehre, Diskussionspapier, August 2006.

Schneider, F. (2010). The Influence of Public Institutions on the Shadow Economy: An Empirical Investigation for OECD Countries, European Journal of Law and Economics, 6/3, 441-468.

Schneider, F. (eds.). (2011). Handbook on the Shadow Economy, Cheltenham (UK), Edward Elgar Publishing Company.

Schneider, F. (2014). The Shadow Economy and Shadow Labor Force: Results, Problems and open Questions, Discussion Paper, Department of Economics, University of Linz, Linz, June, 2014.

Schneider, F. and Enste, D. (2000a). Schattenwirtschaft und Schwarzarbeit - Umfang, Ursachen, Wirkungen und wirtschaftspolitische Empfehlungen, Oldenbourg, München. Schneider, F. and Enste, D. (2000b). Shadow Economies: Size, Causes and Consequences, Journal of Economic Literature, 38/1, 73-110. 
Schneider, F. and Enste, D. (2002). The Shadow Economy: Theoretical Approaches, Empirical Studies, and Political Implications, Cambridge University Press, Cambridge (UK). Schneider, F. and Enste, D. (eds.). (2006). Jahrbuch Schattenwirtschaft 2006/07. Zum Spannungsfeld von Poltik und Ökonomie. LIT Verlag, Berlin.

Schneider, F. and Williams, C. C. (2013). The Shadow Economy, Institute of Economic Affairs, London.

Schneider, F., Buehn, A. and Montenegro, C. E. (2010). New Estimates for the Shadow Economies all over the World, International Economic Journal, 24/4, 443-461.

Schneider, F., Volkert, J. and Caspar, S. (2002). Schattenwirtschaft und Schwarzarbeit: Beliebt bei vielen - Ein Problem für alle?: Eine Analyse der schattenwirtschaftlichen Aktivitäten in Deutschland (am Beispiel Baden-Württemberg) und mögliche politische Konsequenzen, Nomos, Baden-Baden.

Smith, P. (1994). Assessing the Size of the Underground Economy: The Canadian Statistical Pespectives, Canadian Economic Observer, Catalogue, 11-010, 16-33.

Tafenau, E., Herwartz, H. and Schneider, F. (2010). Regional Estimates for the Shadow Economy in Europe, International Economic Journal, 24/4, 629-636.

Tanzi, V. (1999). Uses and Abuses of Estimates of the Underground Economy, Economic Journal, 109/3, 338-347.

Teobaldelli, D. (2011). Federalism and the Shadow Economy, Public Choice, 146/3, 269-269.

Teobaldelli, D. and Schneider, F. (2012). Beyond the veil of ignorance: The influence of direct democracy on the shadow economy, CESifo Working Paper MO3749, University of Munich, Munich.

Thomas, J. J. (1992). Informal Economic Activity, Harvester/Weatsheaf, New York et al.

Thomas, J. J. (1999). Quantifying the Black Economy: 'Measurement Without Theory' Yet Again?, Economic Journal, 109, 381-389.

Torgler, B. (2002). Speaking to Theorists and Searching for Facts: Tax Morale and Tax Compliance in Experiments, Journal of Economic Survey, 16/4, 657-683.

Torgler, B. (2007). Tax Compliance and Tax Morale: A Theoretical and Empirical Analysis, Edward Elgar, Cheltenham (UK).

Torgler, B. and Schneider, F. (2009). The Impact of Tax Morale and Institutional Quality on the Shadow Economy, Journal of Economic Psychology, 30/3, 228-245.

Vuletin, G. (2008). Measuring the Informal Economy in Latin America and the Caribbean, International Monetary Fund, IMW Working Paper WP/08/102, Washington, D.C.

Williams, C. C. and Windebank, J. (1998). Informal Employment in the Advanced Economies: Implication for Work and Welfare, Routledge, London.

Williams, C. C. and Windebank, J. (2001a). Beyond Profit Motivated Exchange: Some Lessons from the Study of Paid Informal Work, European Urban and Regional Studies, 8, 49-61. Williams, C. C. and Windebank, J. (2001b). Reconceptualizing Paid Informal Exchange: Some Lessons from English Cities, Environment and Planning A, 33, 121-140. 